\title{
The Bilingual Writer Stripped off his Bilingual Identity in Indian Literary Scene: Manoj Das and the Politics of Packaging
}

Amarjeet Nayak

Thapar University, India

\begin{abstract}
The position of a bilingual writer in India, who writes in English and a regional language, is a problematic one as s/he has a foot each in two literary traditions-Indian Writing in English and Regional Language Literatures. Instead of being seen as a bilingual writer, the market forces see to it that the writer is seen as a monolingual writer in the respective literary tradition. This paper tries to show how packaging of the bilingual writer in these two traditions contributes significantly towards the split identity of a bilingual writer as a result of which the bilingual writer is stripped off his bilingual identity. I shall do this through an analysis of the packaging of Manoj Das, a prolific bilingual writer in Indian Writing in English and Oriya literary traditions.
\end{abstract}

Key Words: Manoj Das, Packaging, Oriya, bilingual.

The relationship between an author's work and the reader is not a straightforward one. The publishers come in between these two. The publishing house becomes the intermediary between the author and the reader. This is achieved by the way a book is packaged. This paper analyses the packaging of Das's books in Oriya and English. It especially focuses on the way the actual text is sandwiched between selected reviews of the author and/or the text to examine the politics of packaging. It is my contention that Das's books are packaged in such a way that the bilingual aspect of the writer remains largely neglected which furthers the split reception of the writer. Sometimes, even when the bilingualism of the author is highlighted, it is usually not for the purpose of bridging the gap between IWE and RLL traditions. This can be illustrated with the help of the following example.

The most famous Oriya anthology of Das's short stories is Manoj Dasanka Katha $O$ Kahani which received the Kendriya Sahitya Akademi award. It is published by Friends Publishers, Cuttack. The publishers' comments in the book's first edition (1970) are worth noting:

It is a matter of pride that apart from Oriya literature, Manoj Babu is well-established in Indo-Anglian literature. It is well-accepted throughout the world that his stories are the products of a powerful pen. 
The readers in Orissa deserve to read those stories first that have the capacity to enthrall the readers far and wide. (my translation)

From these comments, it is evident that as early as 1970, Manoj Das was recognized as a bilingual writer. But what is more significant is that through such comments, the publishers are trying to enhance Das's value as an Oriya writer, as a writer who hails from Orissa. The publishers are thus identifying a region with a language; in this case, Orissa is being identified exclusively with Oriya. In addition, the publishers are also trying to cash in on the fact that Manoj Das is probably the first writer from Orissa to get some recognition in the realm of IWE and hence that becomes "a matter of pride" for readers in Orissa. Thus, we see the formation of a trend by the publishers of Das's Oriya writings to model him as someone who 'belongs' to a particular state (Orissa) and hence the readers of that region need to be 'proud' of him, and more importantly, have the right to 'get to read him first'. The self-other divide between Oriya and English as well as between the Oriya literary tradition and the IWE tradition is thus propagated, which makes proper business sense for the publishers as this sort of rhetoric has the potential to appeal to the passion of an RLL reader. This, in turn, plants the seed for the split reception of the bilingual writer.

In the second edition (1976) of this anthology, the publishers highlight the fact that Das received the Kendriya Sahitya Akademi award for this work and that it happens to be the first Oriya anthology of short stories to have achieved this recognition. Then an extract from one of Manoj Das's statements to the newspapers after getting this award is produced. From the extract, it becomes evident that even the writer seems to buy into such regionalism when he says, "I have got this award based on the views and recommendations of the critics and writers of Orissa." He does not say "Oriya critics and writers", but "critics and writers of Orissa". This is similar to the publishers of Das's Oriya works identifying Orissa exclusively with Oriya so that their "readers in Orissa" actually is meant to be understood as "readers of Oriya literature".

Manoj Das's Oriya self-translation of his English novel Cyclones (1987) was first published in a serialized form in an Oriya monthly Nabalipi by Vidyapuri publishing house, Cuttack. The novel was then published as a book by the same publishing house in 1992. In the first edition itself the publishers highlighted not only the fact that it was first published in English, but also the names of the three publishing houses that had brought out the novel in English (Sterling publishers, New Delhi, Orient University Press, London, and Facet books International, New York). The publishers also included many quotes by eminent literary scholars on Cyclones. All these reviews, barring one which was aired by All India Radio, are by scholars of IWE and taken from Hindustan Times, The Hindu, The Tribune, The Book Review etc. Quoting reviews by scholars of IWE is on the expected lines as the book had its first incarnation in English. But the second (1993) and third (1998) editions 
of the book also have the same reviews as if there was no critical reception of the Oriya version of the book. The reason reviews by Oriya critics were not included in subsequent editions of the book could be simply dismissed as the lethargy of the publishing house to make the appropriate changes. But whatever be the reason, this exclusion exemplifies another missed opportunity to bring together critical output from both the IWE and RLL literary traditions in one space for a writer who belongs to both. The second and third editions also retain the extract of Das's interview given to his IWE critic P. Raja that was published in Literature Alive (June 1988). This interview clearly brings out his identity as a bilingual writer. But this fact is ignored by his Oriya publishers, who do not include any reviews of his Oriya version.

Das's Saraswati award winning Oriya novel Amruta Phala, which was published by Friends Publishers, Cuttack, in 1996, has undergone seven editions till date and all the editions, barring of course the first one, highlight the fact that it won the Saraswati award. In fact the last page of the seventh edition (2005) loudly proclaims: "Saraswati Award: Considered as the best creation in the whole of Indian literature - Amruta Phala." (my translation). The sixth edition (2004) of the book opens with the following lines by the publishers:

It is a matter of immense pleasure for the Oriya literary world that Amruta Phala received the most prestigious literary award in India the Saraswati Samman. The way the reading public of Orissa has accepted this novel wholeheartedly even before it got the recognition is really tremendous... On behalf of the writer and our publishing house, we express our gratefulness to the reading public of Orissa...(i)

Here also we find the tendency of the publishers to make a direct correlation of a region with a language as if the reading public in Orissa reads only Oriya or in another sense as if the book was read only by the reading public of Orissa. By doing so, the publishers are making sure that not just a sense of belonging to a region is created for the author, but also a sense of identity is created for the Oriya reading public of the state, leading to the identification of the reading public of the state with the author not just on the basis of the common language and literature, but also the region they share. In the present context, such attempts at identifying a geographical region exclusively with a particular language and literature furthers the IWE v/s RLL binary by stressing on the regional specificity of the literature as opposed to the "national" character of IWE, because of the name "Indian" in IWE.

The first edition of Das's Oriya novel Tandralokara Prahari was brought out in 2002 by Friends Publishers, Cuttack, after the novel was initially published in the monthly Oriya magazine Vijaya in a serialized form. The second edition of the novel was brought out the same year as well. In its second edition, the publishers express their delight with the recommendation of the Kendriya Sahitya Akdemi to get it translated into 'other prominent Indian 
languages' as well as with the enthusiastic response of the 'Oriya reading public' to this novel. Thus, the publishers have tried to show the popularity of the writer in the language in which he writes (Oriya) as well as the importance given to his writing in other Indian languages where he is read in translation. However by stating the obvious fact that the novel is written in Oriya and it will be available in translation in 'other prominent Indian languages', the publishers have squarely marketed Das exclusively as an RLL writer.

The edition of Das's autobiographical work Samudra Kulara Eka Grama (1996) published by Grantha Mandir, Cuttack, again does not mention Das's bilingualism, marketing Das exclusively as an RLL writer. However its English translation by the author, published under the title Chasing the Rainbow: Growing Up in an Indian Village_(2004) by Oxford University Press, India, introduces Das as "one of the foremost bilingual authors writing in English and Oriya." It then goes on to list the several awards that have been conferred on Das. The importance of highlighting the prestige and recognition associated with the awards can be gauged from the fact that the publishers devote a new paragraph to bring home the point that "Lately, the Sahitya Akademi has conferred on him its highest honour - the Fellowship - which, according to its constitution is 'reserved for immortals in literature'". Thus, the publishers are making sure that the reader gets to know that the writer is one of the foremost bilingual authors who has won a lot of prestigious awards. However it is worth noticing that the publishers have not bothered to point out that this book is a self-translation by the author from Oriya. This can be seen as an attempt to pass this off as an original English work. While introducing Das as a bilingual writer, the publishers are also keen to market him as an Indian writer and his book as an Indian one. This is evident from not just the way the book is subtitled as "Growing Up In an Indian Village", unlike the Oriya version that did not mention "India" in its title, but also in the way they try to market the book in the following words: "This book will not only appeal to readers nostalgic for a bygone era but will also serve as an invaluable record of village life in early twentieth-century India". So, instead of marketing the work as a translation, the thrust is on marketing it as a book that has nothing to do with RLL. This point gets further mileage from the kind of quotes that litter the book jacket. The publishers have selected quotes from Graham Greene, H.R.F. Keating, Vijay Tendulkar, K.R. Sriniva lyengar, etc., many of whom have praised the inherent Indianness of Das. For instance, according to Graham Greene, "I have...read the stories of Manoj Das with great pleasure...I imagine Orissa is far from Malgudi, but there is the same quality [as Narayan's] in his stories with perhaps an added mystery". By using this quote, the publishers not only certify to Das's international stature, but also highlight the "Indianness" of his writing by providing a telling comparison with an eminently Indian writer, R.K. Narayan. Vijay Tendulkar also echoes the same sentiment. However he goes a step further, praising Das not only for his Indianness, but also for succeeding in bringing Indianness in an 'alien' language i.e. English which, he considers 'not Indian'. According to him, "Manoj Das, like Graham Greene and R.K. Narayan, is a deft spinner of 
yarns. Narrating an Indian experience in a language which is alien or not Indian, without losing the original Indian charm and ethos is a difficult task. Das succeeds in this like Narayan".

Das's anthology of short stories The Dusky Horizon and Other Stories (1989) was published by B.R. Publishing Corporation, New Delhi, under the series titled "New World Literature Series". The book is marketed here as part of world literature though a look at the first 30 books in the series shows that all these books (fictions, poetry, translations and critical pieces) are by Indians and with a few exceptions are all about India and Indian literature. This can be seen as an attempt by the publishers to place Indian literatures on the world map as 'new world' literature. "A Note from the Publishers" given in this book is very interesting on many accounts. It begins by highlighting the writer's bilingualism and claims that he is "one of the very few successful bilingual writers in India". However, it goes on to say that "His creative gift finds expression not only in English but in Oriya, the language of his home state of Orissa". Here we find an attempt to identify a region (Orissa) with a language (Oriya) and thus create a 'local' versus 'global' identity of two languages, those of Oriya and English, respectively. Thus, the recognition of bilingualism by the publishers is undermined by their appreciation of Oriya and English in terms of a local vs. global kind of framework which does not put the languages or the literary traditions in conversation with each other.

Moreover like the OUP edition of Das's autobiographical work Chasing the Rainbow which markets the book as well as the writer as "Indian", the publishers of this book also try to project Das as an Indian writer in both theme and language. The note from the publishers quotes Mr. Batstone who says, "One of the intriguing qualities of his English writing is the lack of clichés - the totally unexpected use of words and their collocation, arising, perhaps, from the exact and fresh description of his visual imaginings of Indian situations and agents, of a kind that an English writer would not have...." In fact Mr. Batstone emphasizes Das's uniqueness by naming his Indianness as his vantage point and he tries to underline this point by comparing him with writers such as Saki, O' Henry, Hardy, etc.: "Manoj Das has been compared, as a short story writer, to Hardy, Saki and O' Henry. This is misleading; he is like no one but Manoj Das. Indeed it would be a serious defect if he wrote like an Englishman or an American...And he writes as an Indian indeed, with a wholly Indian view of things, from an Indian background".

It is pertinent to note that when Mr. Batstone is dismissing the notion of Das being compared to Saki, O' Henry etc., he is actually trying to dismiss the label given to Das by another Western critic Eric Hughes that we find in the short story collection titled Short Stories (1969), published by Triveni Publishers, Madras. This is what he has to say about Manoj Das as early as 1969 - "Indeed a very good writer, with great sensibility and gift for the unexpected, but quite logical ending, not unlike the American writer O' Henry and the British, Saki, and with greater depth...". On this evidence, it is clear 
that the publishers are trying to cash in on the international recognition of the author and in the process undermine the importance of the writer being a bilingual by completely ignoring the critical reception of his regional language writing. The note of the publishers also tries to point out the writer's success in terms of awards and publication by international journals - "The inaugural number of 'Ascent' (University of Illinois) chose to include one story from abroad. It was 'A Night in the Life of the Mayor' [by Das]. The Long Island University brought out an interesting anthology of meaningful stories of Brooklyn and placed them side by side with significant current stories of the world. The story they chose from India was 'Lakshmi's Adventure' [by Das]..."

Another anthology of short stories by Das, Bulldozers and Fables and Fantasies for Adults (1990) was also published by B.R. Publishing Corporation, New Delhi, under the series titled "New World Literature Series" and is packaged along similar lines.

The Lady who died one and a half times and other Fantasies (2003), published by Rupa, New Delhi, also tries to highlight Das's international stature and Indian style by pointing out Vijay Tendulkar's comparison of Das with Graham Greene and R. K. Narayan. To give further credentials to Das being an 'Indian' writer and having a place in the pantheon of IWE, the publishers have decided to include an extract from a review by "The Sunday Standard" which says - "As a storyteller Manoj Das has few rivals in the contemporary Indo-English world". Thus, the packaging is such that the reader gets to know the difficulties involved in the writer's art of writing in a language 'which is not his mother tongue' and is 'alien or not Indian' and also that the writer has overcome these obstacles so much so that he 'has few rivals in the contemporary Indo-English world'. This completely leaves out the other aspect of Das, that of him being a prolific and successful writer in Oriya as well.

Almost all the publishers of Das who publish his English works while paying lip service to his bilingual identity, take pains to market him as an 'Indian writer' with 'Indian sensibilities, ethos' etc. Penguin Books India which brought out his short story collection Farewell to a Ghost (1994) introduces Das as a bilingual writer and lists the various awards that he has got in the two languages. But on the back cover, it has two quotes, one by M. V. Kamath and another by some anonymous critic, both of whom extol Das's 'Indianness'. Kamath's quote goes like this - "What is Manoj Das? A social commentator? A psychiatrist? A sly peeper into people's hearts? Or just a plain storyteller? Manoj Das is all these, and an incorrigible Indian besides". The other quote says that Das's stories catch 'a rhythm of life that is typically Indian....' This sort of focus on Das's "Indianness" can be seen as a major commonality in the way Das is marketed in IWE, as opposed to him being marketed as a monolingual Oriya writer in RLL. 
Chandamama Publications, Madras, has published many of Das's children's tales in English like Equal to a Thousand and other Tales (2005), The Magic Tree and other Tales (2005), etc. Each of these editions portrays Das as 'a foremost fiction writer of India' thus attempting to market his "Indianness", just as the other publishing houses of Das's English works do.

The Sahitya Akademi published Tales Told by Mystics (2002) marketing Das as a "master story-teller of our time, one of the best loved creative writers of India, recipient of Sahitya Akademi Award, the Padmashree and Saraswati Samman". Das's Indian identity and his recognition in terms of the awards seem to be the major criteria of marketing Das here, as well.

By trying to portray Das as an Indian writer in the tradition of R.K. Narayan and mostly ignoring his Oriya works, the English publishers are trying to take the writer in isolation and give him the exclusive identity of an IWE writer. By doing so, they are obliterating one half of the bilingual writer's identity. Thus we see that even if the English language publishers of Das do mention that Das is a bilingual writer, the way they portray his output in terms of the critical reception he has received, it seems as if the writer writes predominantly in one language i.e. English. Secondly he is portrayed as an 'Indian' in terms of his writing style and language though there is no effort to describe his 'Indianness' in terms of his bilingualism. Thus, while the publishers of Das's Oriya books market Das as only an RLL writer, Das's publishers in English market him exclusively as an IWE writer.

It is pertinent to note that whenever there appears to be some reference to Manoj Das's English works in the packaging/marketing of his Oriya works, its purpose is purely marketing, to add to Manoj Das's prestige by appealing to the greater power of English within the literary marketplace. As such, there is no real attempt to put the two literatures into conversation with each other; one is simply used to boost the market value of the other, something similar to saying that Kalidas is the Indian Shakespeare!

From the above discussion, it is proven beyond any doubt that packaging as a prominent market force plays a major role in shaping the perception of the reading public. In case of a bilingual writer like Manoj Das, packaging has seen to it that both his identities (IWE writer and RLL writer) are never brought together to form a coherent self, that of a bilingual writer, ensuring that split reception is the fate of a bilingual writer.

\section{Works Cited:}

Das, Manoj. Amruta Phala. Cuttack: Vidyapuri Publishers, 1996.

-------Bulldozers and Fables and Fantasies for Adults. New Delhi: B. R. Publishing House, 1990.

Chasing the Rainbow. New Delhi: Oxford University Press, 2004.

------Cyclones. New Delhi: Sterling Publishers Pvt. Ltd., 1987. 
-Equal To A Thousand and Other Tales. Chennai: Chandamama Publications, 2005.

-------Farewell to a Ghost. New Delhi: Penguin Books India (P) Ltd., 1994.

-Manoj Dasanka Katha O Kahani. Cuttack: Friends Publishers, 1971.

Samudra Kulara Eka Grama. Cuttack: Grantha Mandir, 1996.

Short Stories. Chennai: Triveni Publishers, 1969.

-Tales Told By Mystics. New Delhi: Sahitya Akademi, 2002.

-Tandralokara Prahari. Cuttack: Friends Publishers, 2002.

-The Dusky Horizon and Other Stories. New Delhi: South Asia Books, 1990.

---The Lady who died one and a half times and other Fantasies. New

Delhi: Rupa Publishing House, 2003.

-The Magic Tree and Other Tales. Chennai: Chandamama Publications, 2005.

Amarjeet Nayak is Assistant Professor, School of Management and Social Sciences, Thapar University, Patiala, Punjab, India.

E-mail: n.amarjeet@gmail.com 